Dominika Żukowska

\title{
The Combination Of Ethics And Aesthetics With Regard To The Representation Of The Body In Culture*
}

Human corporeality is present across the whole of history. Contemporary attitudes towards the body seems to be an important determiner of changes in mentality. The comparison between the affirmation of the body in the Catholic Church and contemporary signs of human degradation through corporeality are of interest. On the one hand, there is enslavement through consumerism and utilitarianism, and on the other hand the boosting of the body's confidence by means of constant reference to human corporeality.

The opinion that Christianity presents a negative attitude towards corporeality is a misunderstanding. This image could be influenced by medieval ascetic practices, which were supposed to form spiritual perfection by means of rigorism and internal discipline. Asceticism, practiced and highly valued up to this day in Christianity, is not a result of contempt and aversion towards the body, but of the experience that one of the paths towards God leads through spiritual development supported by giving up sensual experiences ${ }^{1}$. The Catechism of the Catholic Church indicates several aspects of the truth concerning human corporeality and respect for the body in Christianity; the body takes part in the dignity of the image of $\operatorname{God}^{2}$; God himself became a human'; The Eucharist, as the body of Jesus Christ, became a symbol of salvation of $\operatorname{man}^{4}$; the body is the temple of the Holy Spirit, a sign of the beauty of God ${ }^{5}$; according

STV 48(2010)1.

Cf. Apoftegmaty Ojców Pustyni, PSP 33, vol. 1, 292, Warsaw 1986.

KKK, 364.

KKK 457.

KKK 1333.

KKK 2519. 
to the Biblical parable, a woman was created out of the body of $\operatorname{man}^{6}$; man can control his desires, particularly sensual pleasures ${ }^{7}$; man should control his desires also due to the dignity and freedom of other people ${ }^{8}$; we will rise from the dead in the same bodies?

\section{Corporeality In History}

The first Christian heresies were connected with the rejection of human corporeality as a source of evil. Up until now, the gnostic spirit affirming only the spiritual sphere of man has been present in current philosophies and outlooks. Gnosticism (from Greek gnosis - having knowledge) was a very interesting compilation of Iranian, Persian, Egyptian, Judaist and Christian beliefs. The basic premise of gnostic philosophy is the necessity to break up everything in the world that is connected with the body because only the spirit is a sign of fulfilment and salvation. Due to this fact, the relationship between man and woman was dirty, and living in the body called for undertaking effort, liberating oneself from the body. According to Plato and Greek philosophy, the soul is a divine element and must be freed from the body. Gnostic cosmology was based on the opinion that there is dualism in the world: good-evil, light-darkness; the demiurge of the Old Testament was just, but not merciful, the creator of matter, the reason for everything which is impure in the world, and the God of the New Testament, the creator of everything that is spiritual. The early Christian

writers, such as Irenaeus of Lyon ${ }^{10}$, or Tertullian ${ }^{11}$, had to deal with gnostic teachers in defence of the faith. They formulated the first teachings about the dualism of body and soul in man as two necessary elements which supplement each other in their writings, based on philosophy and logic.

The apologists were supported by the Greek love of art. Even though the great ancient philosophers called for liberation from the body, the then art showed that the beauty of the soul is represented by the body. Right up to this day, ancient sculpture and the manner of presenting figures constitutes a model for artists. The Greek admiration for the body which needs to pursue

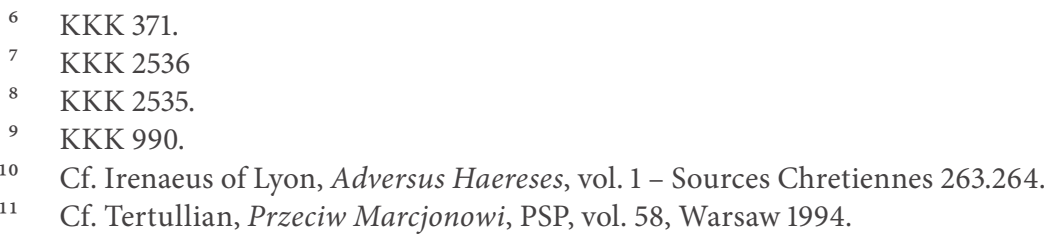


perfection in order to represent the extraordinary character and beauty of the soul, was an inspiration for Christian $\operatorname{art}^{12}$. What is more, the Church Fathers in their writings additionally emphasized the meaning of the creation of man (also as a corporeal person) in God's own image and likeness (Gen. 1:26). The body, which was underestimated, outside Judaism, started to participate in the dignity of God's image.

There is no place here for semantic deliberation connected with the Biblical understanding of the word "body". We should bear in mind that even Saint Paul explained the difference between sarx, body understood as corporeality, as a whole human and soma the physical body subject to desire ${ }^{13}$. The very fact of introducing such notions in Judaism and their adoption by the first Christians shows strong connotations between man and body.

The history of affirmation and degradation of the "body" is extremely rich and this topic was raised many times. In this paper, we will only analyse our age. The departure from metaphysics is a significant feature of the contemporary interest in the body. One of the first thinkers who radicalized thinking about the human body was F. Nietzsche ${ }^{14}$. He announced the death of God, satirized the soul and introduced the notion of the birth of super humanity. His opinions on the issue of corporeality are important, because as of that moment it was believed that man could fulfil himself by means of using the body. Nietzsche gives up metaphysics, belief in eternal life. He is liberated by nature. This is the characteristic opinion of some philosophers who think that the philosophy of Nietzsche began atheistic trend, as well as the utilitarian and consumerist vision of the man. According to Gabriel Marcel (and later more broadly to John Paul II) man starts to care more for "having" than "being"15.

To this day, the Christian concept reminds us of the fact that the body is a manner of representing human beings, that it is necessary, but not a sufficient rationale. The existence of a person is connected with an independent soul which cannot function apart from the body (waiting for the Last Judgment is a separate topic. The soul exists here without the body, but only in the perspective of the Resurrection. The body, on the other hand, as dust (Gen. 3:19), awaits a new life).

12 Cf. E. Jastrzębowska, Sztuka wczesnochrześcijańska, Warsaw 1988; M.L. Bernhard, Historia starożytnej sztuki greckiej, 4 volumes, Warsaw 1993; Z. Abramowiczówna, O sztuce starożytnej, Toruń 2000; H.G. Gadamer, Aktualność piękna: sztuka jako gra, symbol i święto, Warsaw 1993; P. Evdokimov, Sztuka ikony. Teologia piękna, Warsaw 2006.

13 I. Mroczkowski, Osoba i cielesność, Płock 1994, 45.

14 Ibid., 23

15 G. Marcel, Być i mieć, Warsaw 1962. Cf. Jan Paweł II, Evangelium vitae, 98. 
Karol Wojtyła developed a definition of a man. He wrote that a man is an entity not only by means of self-awareness and self-determination but also by means of his body which allows him to act. "The notion of 'spirit' and 'spirituality' is often, somewhat one-sidedly, identified with the denial of the purely material nature of man. By "spiritual" we indeed mean an immaterial factor which is inherently irreducible to matter. (...) Spirituality is open to intuition as well as to an unfolding analysis. This shape, the shape of transcendence, is concretely that of human existence: it is the shape of human life itself. Man both lives and fulfils himself within the perspective of his transcendence"16. This is a repetition of the definition of the soul already presented in the Middle Ages by Saint Thomas Aquinas who rebuilt this concept with Christianity in mind with the use of Aristotle's beliefs, determining the soul as a form of the body. As a side note, the soul and body cannot exist separately, even though these are separate components because the existence of one element justifies the existence of the other. Therefore, death constitutes a split for the believers, which can only be fixed by the Resurrected Christ.

\section{Contemporary Times}

It seems that our contemporary time is the time of paradox. On the one hand, we witness the deification of the body, and its degradation on the other. The "body" is present in each dimension of a culture. It became a cultural mark. Effective diets, new clothes designs, plastic surgery, beauty and wellness salons, healthy food, water from natural sources is all supposed to serve the body, not man. It is supposed to improve his external image, because the body is an "advertisement" of a person. The body is a person for sale: advertising agencies, the media face of a TV presenter, a best-dressed politician or businesswoman. The perfect image is promoted nowadays, someone who is well-cared for, and a slim and athletic body is the key to success and the path to having a career. The body is being contradicted, people are fighting the body. Breasts are enlarged, noses are subject to surgery. We buy cream in order to fight wrinkles. The body now seems to be something strange for man, something 'separate' which needs to be fixed. Culture has always created some criteria for the canon of beauty, but nowadays it is strongly supported by TV and advertisements which are (seemingly) all about the improvement of human corporeality. The most important 
thing is that man should give up money (a part of himself), hard work, and time. Suffering, death, old age and sickness have been eliminated imperceptibly from the public sphere. We have hospices and retirement homes. The latter is however more of an enclave for elderly people who get separated from the world and their family and die alone. There are new health problems which were not termed disease before: hyperactivism, hyperactivity, depression and identity problems. Due to problems concerning sexuality, contemporary psychology has even created new concepts with the body considered a "stranger." The concept of gender was created and it describes a set of features and behaviours, gender roles and stereotypes ascribed to both men and women by society and culture where biological gender is not separated but is described as sex.

On the other hand, contemporary art becomes increasingly more provocative. The most frequent topic is breaking the taboo that is human nudity which was hidden throughout the centuries. Popular culture exploits the body as much as possible. Artists look for topics combining sex and the sacred. The sacred entity is lost in mass culture, and its place is taken not by the profane but by banality. Art looks for new means of expression, new techniques and artistic forms. However, the result can hardly be called beauty which inspires.

The Christian message on nudity is unambiguous. "Then the eyes of both of them were opened, and they realized they were naked; so they sewed fig leaves together and made coverings for themselves." (Gen. 3:7). Saint Augustine, Doctor of the Church, explained in the commentary to this fragment of the Holy Bible that nudity was not something disgraceful and that lust was controlled before original sin. Nudity was a symbol of purity and similarity to the Creator, a symbol of freedom and simplicity ${ }^{17}$. Looking at nudity was connected with the belief that we give ourselves to the other person, standing before the other person in truth, without mystery. To this day, nudity is a symbol of the state of human existence for Christians where everything is revealed and where we live in truth. The medieval spiritual rule went as following: strip oneself to the core which means pursuing the state before original sin. After the fall of the first parents, nudity was combined with sexuality, an unstructured desire. Due to this, the Church Fathers said that nudity was covered with the cloth of baptism and the tunic of resurrection ${ }^{18}$. The strict attitude towards nudity was not contradictory to the affirmation of the body. It was a result of an awareness of sin and indicated a lack of balance in nature. It seems that it was also a response

17 S. Kobielus, Nagość jako symbol i wartość w kulturze średniowiecza, "Communio" 64(1991)4, 106.

18 Ibid., 108 
towards the excessive cult of the body in Greek and Roman art, especially when it came to nude sculptures of the gods. As far as Christian art is concerned, the image of nudity was frequently connected with the worshipped body: the nudity of the resurrected Christ, the nudity of man during the Final Judgement or the nudity in paradise.

The Biblical message shows that man looked for his identity as at the moment of his creation. His external appearance, his body, made him distinct from the world of other living creatures. Adam also noticed that he participated in the visibility of the created world by means of the body. The description of creation (Gen. 2,1:25) shows that the body played a crucial role during the first encounter between man and woman. Woman was bone of his bones, flesh of his flesh. It could also be said that man is able to define himself only at the sight of woman. He only finds himself during an encounter with another human being.

According to theologians, the Biblical "I heard you in the garden, and I was afraid because I was naked; so I hid" (Gen. 3:10) is about the radical change in man after original sin. We need to understand this in order to explain the modern attitude of man towards the body. According to Catholicism, man is similar to God through the body. However, we lost the initial certainty of God's image as expressed in the body ${ }^{19}$. Sexual and immanent shame emerges. Man ceased to identify with his body. Instead of being similar to God, by means of the gift for the other, he becomes similar to animals. He is subject to sexual desire and cannot control it.

Works of culture, especially works of art, provide "being the body" and experiencing the body with an over-material character. Contact with the body as a topic for art gains an aesthetic dimension. Contact with other human beings should always favour the aesthetic experience of purity. It should execute the subjective dimension of the gift. As far as ethics is concerned, the anonymity of the gift of the body in art is problematic. The human body, the naked body, (according to John Paul II) should always have the significance of a gift, a person for a person ${ }^{20}$. The artistic objectification of the body is a kind of separation from this interpersonal gift system. Sculpture, painting and film is not able to keep this function of the gift of the body. It has common sense.

"Moving" the body to the public sphere goes above the concept of communion of the people, above original shame and the need for the intimacy of our own body. According to the pope, this truth should be reflected in the artistic

19 John Paul II, Mężczyzną i niewiastą stworzył ich, Vatican 1986, 115.

20 John Paul II, Etos ciała a dzieła kultury artystycznej, in: Mężczyzną..., op. cit., 241. 
order. This is the only way to avoid the objectification of the human being ${ }^{21}$. The culture of the body is a transformation of matter, that is the body in the female and male form. In his criticism of culture, John Paul II talks about working on one's own ethical and moral sensitivity. The artist must want to show the truth of man in his body, in his female and male character. Then, the audience needs to make an effort in order to read this intention. The artist needs to maintain contact with the audience. However, many contemporary pieces of art seem to be art for art's sake, thoughtless messages. We should create an atmosphere fostering purity so that every contact with the human body is appropriate for human dignity. "True and responsible artistic activity aims at overcoming the anonymity of the human body as an object 'without choice.' As has already been said, it seeks through creative effort such an artistic expression of the truth about man in his feminine and masculine corporeity, which is, so to speak, assigned as a task to the viewer and, in the wider range, to every recipient of the work"22.

However, contrary to the idealistic vision of the pope, consumer society creates a type of narcissistic culture, where the main concern for the human being is its healthy and beautiful appearance. The body is goods for sale. Women are convinced that a model is a media authority for them. Due to this fact, women (as a product of creation) should constantly be fixed and improved. "Put bluntly, the part that was not successfully fashioned by nature should be improved"23. The narcissistic trend, hitherto reserved for the fairer sex, now also touches men. This fact only confirms the fear expressed by the pope that nowadays the body is only limited to an image offering success, self-fulfilment, and that man is limited to the functions of his own body. This trend is promoted as the most important value in life. People who lack this advantage will be placed outside society $^{24}$.

\section{The Tasks Of Culture}

The task of culture is to describe and show the beauty of human beings, reach the truth of his humanity. The works of culture, especially works of art, make the dimensions of "being the body," "experiencing the body" teach, inspire and

21 Ibid., 243.

22 Ibid., 251

23 P. Tyszka, Kupuję nowa twarz. O ciele idealnym., in: D. Czaja (ed.), Metamorfozy ciała, Warsaw 1999, 56.

24 Ibid., 73. 
suggest the answer to the following question: who is man? Due to this relationship, the body became a popular theme for literature, music, sculpture and painting. Every contact with such a work of art is an aesthetic experience for the recipient. Such a perspective, which provides human beings with reflection on his own existence, becomes a work of art. A work of art is always some kind of step towards perfection. A work of art is beautiful insofar as it awakes the good in the human being, and is aesthetic at the same time.

The task of culture is meeting with another person, a relationship based on creative dialogue. Talking about the body in culture requires the unity of the creator and the recipient, their mutual communication. The aesthetic experience, the experience of beauty is always something good arising out of the intention of the person explored, but also of the intentions of the artist who wants to show a positive value by means of his work of art - this is truly a work of art. The relationship between the creator and the recipient is mutual and leads to the enrichment of both entities.

The body or face, image or profile of a person is a form of particular expression of humanity.

The interesting concept of 'face recognition' as a meeting place was presented by Father Józef Tischner. The sources of his meeting philosophy ${ }^{25}$, which is in other words can be called a dialogue, reach the notion of drama, where man and his life is the key. Man, as described by Tischner, takes part in the drama, where his life is a stage. By means of making contact with different people, we participate in different shows, where we constantly live our lives in a different manner. Man is inherently dramatic, which means that he naturally opens to the world - the stage. However, being a dramatic person is for Tischner something completely different than being man or woman, a child or an elderly person. It is the awareness that you are a subject for yourself and other people and that you bear the responsibility for "destruction or salvation" yourself ${ }^{26}$, which is important. This means that a person may accept his character and that the drama will end in salvation. He can also reject his character and lose himself, leading to tragedy.

25 Through contemporary philosophy, in criticising European rationalism and referring to the tradition of Judaism, he develops a dialogical vision of human philosophy; the following people are the authors of this philosophy: F. Rosenzweig, M. Buber and F. Ebner. The philosophy of dialogue was creatively developed in Poland by J. Tischner who created the philosophy of drama.

26 J. Tischner, Filozofia dramatu, Kraków 2006, 8. 
Father Tischner uses notions developed by philosophers preceding him: Husserl, Heidegger and Levinas. He interprets their opinions in the context of the concept of drama. This is the way he reaches his idea on dialogical openness towards other human beings. The key notion in this drama is the face as an expression of the whole human being. The face is the core of meetings and the beginning of relationships with other human beings, as well as the beginning of human existence in culture at the same time.

"Another person is present in me - or near me - by means of the claim which he causes in me. (...) Another person is present near me by means of what I should do for him; I am present near him by means of what he should do for $\mathrm{me}^{\mathrm{N2} \text {. }}$.

\section{Making The Gift Of The Body Common In Art}

The presence of a man, the message of a gift - the body - is executed by making the body common in culture. This should be a positive phenomenon. It is supposed to show beauty which should offer something positive for each recipient. According to Father Tischner, beauty is a property which cannot be appropriated. Therefore, talking about the man is always connected with talking about his character of a subject. According to Tischner, the meeting of people is at the same time a chance for experiencing the beauty of another human being. It is about the beauty which is a result of the value provided by the existence of another human being ${ }^{28}$.

This issue is similarly understood by John Paul II. However, he directs his thoughts to the meeting of people as a means of contact with a piece of art, the fruit of culture. In order to talk about the body in culture, it is necessary (according to the pope) to make this a topic for a piece of art. Therefore, it will always be some kind of "objectification" of the body. He notices the body in film, painting, photography and sculpture usually becomes a model which is subject to processing. The level of such processing is dependent on the medium which creates the show. The negative value, which is noticed by the pope in artistic reproductions of the body, is the necessity of its objectification. As far as film production or the photographic act is concerned, the body becomes something anonymous. Direct contact with the human body and its elementary functions, that is being

27 Ibid., 12-13

28 Ibid., 92. 
"for" has been lost. When the body becomes a work of art it is deprived of its subjective function of telling us about man. It starts to be a carrier of another sense than the original one in the artistic form. In each of the dimensions of art performance, the body becomes a product of art, which is widely available for many recipients. That is why John Paul II asks the following questions: is it possible to present the body in such a manner that will preserve its original sense, the original message of giving? Is the presentation of a naked body aesthetic and ethical at the same time? Is it ethical to present the body anonymously, if this results in the risk of losing the whole sphere of meaning appropriate for the male and female body, as well as mutual relations between them?

It seems that similar questions are asked by Father Tischner. However, he does not deal directly with the means of presenting the body in culture. He speaks of the ontic relation, of cognition on the living level, which always constitutes the basis for culture. The analyses of Father Tischner are therefore something primal when it comes to the image of the body in art, which was already created. They reach issues which should be touched by each artist and creator in a more or less conscious manner.

The analyses of John Paul II reach the material reality in which we participate and in which the ontic questions of Father Tischner are present insofar as they are expressed in a form called the practical execution of this philosophy. In each of the dimensions of art, according to John Paul II, regardless of the level of their perfection and similarity to the original, the human body "loses that deeply subjective meaning of the gift. It becomes an object destined for the knowledge of many"29.

According to Tischner and John Paul II, culture pursues the discovery of the nudity of man. As far as the nudity of the face is concerned, the face without a mask looks for the truth about "the other," whom we meet, and at the same time is searching for one's own identity, our self-determination in the world thanks to meeting "the other." This issue is undertaken by the pope, but in a slightly different form. The pursuit of the presentation of nudity was something natural in primitive cultures. The pope looks at the current culture and makes the assessment that society has kept the memory of a betrothed nature of the body. It is visible even during an appointment with a doctor, when one has to get naked. The natural feeling of shame emerges, which is supposed to protect this gift. This shame reminds us of the fact that the naked body may be a gift only for one person. Even though John Paul II expresses his thoughts

29 John Paul II, Mężczyznq̨..., op. cit., 242. 
from the point of view of Christian anthropology, he seems to present the truth for all mankind.

The objection presented by Christian circles towards pornography and pornovision is a result of the fight for the preservation of the body as a gift "for." The anonymous nudity of the body and different techniques of its reproduction aim for profits and material benefits gained from the humiliation of the body and reducing it to the role of an object. The correctness of the gift and giving the gift is no longer sensible. The body becomes public property in culture. That is why, according to John Paul II, it loses its function of interpersonal communication ${ }^{30}$.

This issue is present (however, to a lesser degree) in analyses by Father Tischner ${ }^{31}$. The beauty of the human body, the beauty of the face has a fundamental goal. It is a message of value and a gift of value. It makes a person feel dignity arising out of an encounter with another person. The aim of the encounter is to discover one's own dignity and beauty. Man is the carrier of positive values, which arise out of the very essence of his existence. At the same time, the value of his existence points to the beauty of this life. According to Tischner, contact with the other and the beauty of the other results in openness. Both entities (the learning and the learned) acquire an appropriate sense.

\section{Ethical Boundaries Of Body Presentations}

The topic of the human corporeality carries ethical issues. Since culture tackles the issues most important for man, it should also deal with the topic of corporeality and the most beautiful message existing between men - love. Are there any boundaries of discussing the body in culture?

Both Father Tischner and John Paul II thought that the concept of ethics and aesthetics create boundaries inside human conscience. This combination of ethics and aesthetics is somehow connected with the topic of communicativeness. Mutual relations between man and woman - people who are aware of the mutual gift - creates communion. The similar function of communion should be fulfilled by the artist towards the recipient. The artist is responsible for his own work of art. When undertaking this topic in any of the branches of art or by means of different techniques, the artist must be aware of the complete truth of the subject presented by him. If he deals with presenting the body, especially

$30 \quad$ Ibid., 247.

31 J. Tischner, op. cit., 90-94. 
its nudity, he is morally obliged to present it in a way which keeps the intention of the subject and which brings itself closer to the truth on the subject. The task of the artist is to establish communication and build connection with the recipient of his work of art. The artist is supposed to provide the recipient with his internal world of values by means of his creative idea. The recipient, invited by the artist to look at the work of art, interacts with the individual vision of the artist, a culturally adopted attempt to objectivize the work of art. Apart from his original idea, the artist, as the creator of culture, has to create works of art which constitute the message reflecting the truth. As far as the body is concerned, the true artist processes the issue of nudity, which does not lead to lust, but wakes the desire to look for deeper values, for the truth.

According to Tischner, the artist shows beauty, but as he writes, "beauty should not need anyone, even the artist" ${ }^{\prime 2}$. Tischner expresses a statement similar to that of John Paul II that the man, the artist, by means of his art, represents (with more or less success), the truth of the man and the beauty of creation. The task of the artist or other creator of art is to serve ethics by means of aesthetics.

However, there are some works of art (or reproductions to be precise) which do not evoke positive feelings in the recipient. They "arouse objection in the sphere of man's personal sensitivity - not because of their object, since the human body in itself always has its inalienable dignity - but because of the quality or the way it has been reproduced, portrayed or its artistic representation" ${ }^{33}$. If the recipient's reaction is objection, disapproval, if he feels dissonance with his own sensitivity, this is probably when we have to deal with the objectification of man. We see the presentation of the body, which serves something completely different than looking for truth on the subject.

That is why John Paul II emphatically emphasizes the artist's responsibility for his own work of art. The aesthetics of his work of art should raise ethical sensitivity, should be the strength and reason for ethics. However, the responsibility lies both with the creator and recipient of the work of art. The artist should look for such forms of body presentation, which will show the dignity, purity and betrothed character of the body to the level closest to the truth. On the other hand, the recipient must express an authentic desire to understand the intention of the artist. He is also obliged to make some effort in order to shape the truest image of the body. It is dependent on him whether he will make an effort to search for the truth or, as suggested by John Paul II, will "remain merely

32 Ibid., 99f.

33 John Paul II, Mężczyznq..., op. cit., 249. 
a superficial consumer of impressions, that is, one who exploits the meeting with the anonymous body-subject only at the level of sensuality which, by itself, reacts to its object precisely without choice" ${ }^{34}$.

The reflections of Father Tischner on the topic of relations between ethics and aesthetics do not touch the manners of presenting the body in culture in a direct way. Just like John Paul II, he also talks about the necessity of such interpersonal relations, which will result in studying the truth of man. This results in his analyses of the face and their consequences with regard to people meeting each other. Father Tischner uses the concept of "face," John Paul II talks about the body in general.

Both of them consider the body-face a great work of art created by God. Our whole existence here on Earth is a path towards discovering God, who placed his image in the work of art, that is man and his corporeality.

The reflection of both philosophers seems extremely important in the current discussion on the role of culture in the process of upbringing man. Society awakens from stupefaction and becomes an active and demanding recipient. As an example: we feel irritated by advertisements, we usually prefer European cinema, not thoughtless Hollywood films. The trendy, naturalistic model of presenting the body starts to repel the audience. Popular culture seems to deprive man of his own identity and individuality by means of many shallow and unethical propositions. Therefore we look for spirituality and we probably find it in our corporeality - in the value of the body in culture. 